\title{
Freedom, Love, Nobility: The Falkenmotiv in Medieval and Modern German Literature, with an Emphasis on Werner Bergengruen's "Die drei Falken”
}

\author{
Albrecht Classen (Corresponding author) \\ University of Arizona \\ United States \\ E-mail: aclassen@arizona.edu
}

Received: June 30, 2021 Accepted: July 30, 2021 Published: August 2, 2021

doi:10.5296/ijch.v8i2.18897 URL: https://doi.org/10.5296/ijch.v8i2.18897

\begin{abstract}
Medieval literature has deeply shaped modern literature through many different channels. Sometimes entire works were translated or paraphrased into modern languages, sometimes medieval motifs, themes, figures, or concepts impacted modern texts. This article examines one remarkable example, Werner Bergengruen's highly popular novella "Die drei Falken" (1928) the source of inspiration of which was loosely Boccaccio's story told on Day V, no. 9 in his Decameron (ca. 1350). Throughout time, the falcon has regularly symbolized courtly love, nobility, and the desire for individual freedom. After a discussion of Boccaccio's text and a selection of medieval examples where the same motive appears, this article examines how Bergengruen transformed the symbol of the falcon into an expression of human nobility and deeply felt desire for personal freedom.
\end{abstract}

Keywords: falcons as a literary motif, Nibelungenlied, Der von Kürenberg, Werner Bergengruen

\section{Medieval Themes and Motifs in Modern Literature}

Contrary to many assumptions that the Middle Ages might matter little in modern literature, the opposite often proves to be the case insofar as there are countless examples of poems, novels, short stories, plays, and other types of texts at least since the early nineteenth century in which medieval themes, topics, materials, ideals, motives, and elements emerge more or less significantly (for the situation in the history of modern German literature, see Grosse and Rautenberg). The most dramatic examples with a global success were certainly J. R. R. 
Tolkien's Lord of the Rings (1937-1949), J. K. Rowling's Harry Potter (1997-2007), and David Benioff's and D. B. Weiss's Game of Thrones TV movie series (2011-2019) (e.g., Risden). Although in those works the Middle Ages are often evoked only indirectly, mixed and combined with numerous aspects of fantasy and imagination, altogether this proved to be the perfect recipe for the enormous popularity of these works. But the Middle Ages have also appealed to many other authors and movie makers in countless languages until the present day for many different reasons, such as Japanese or Indian movies (see, for instance, https:/www.imdb.com/list/ls050050367/). Romantic ideals, dream images, curiosity, adventures, heroism, and the desire to find medieval origins of the Amazon-like modern woman have all played a significant role. At the same time, numerous German writers such as Robert Musil, Hermann Hesse, Peter Handke, Adolf Muschg, and, most recently, Gabrielle Alioth have turned to medieval history, philosophy, theology, and courtly literature as sources of inspiration (Classen 1996; Classen 2000).

This phenomenon has not been limited to German-language literature but proves to be a global one. The entire world of fairytales, for instance, whether by the Brothers Grimm or Christian Andersen, mirrors the huge impact of medieval themes on modern culture (Wagner; Zipes). The case of the Tristan story, highly popular particularly in the late twelfth and early thirteenth centuries and then again since the nineteenth century, intriguingly underscores this phenomenon, if we consider not only the outburst of scholarly and literary interest since the late eighteenth century, but also such famous examples as Richard Wagner's Tristan und Isolde (composed in 1859, performed for the first time in 1865), Thomas Mann's Tristan novella (1903), and countless other adaptations and translations until the immediate present (including modern movies and music; Dallapiazza, ed.; for a very useful list of contemporary responses to the medieval material, see the journal Tristania 1975-2009, 25 vols.).

\section{The Medieval in Werner Bergengruen's Die drei Falken}

In 1928, the highly popular author from Riga (today, Latvia), Werner Bergengruen, published a short story, Die drei Falken (The Three Falcons), which follows the same trend, although the source of inspiration can be traced more directly to Boccaccio's Decameron (ca. 1350), a famous collection of 100 stories told by ten tellers over the period of ten days, who want to escape the horror of the Black Death. It might be debatable whether the Decameron still belongs to the Middle Ages or already to the early Renaissance, but one of the stories contained in it, focusing on the famous falcon motif, both harkens back to the traditional medieval culture of hunting with falcons and proved to be the springboard for a long-term influence on the modern world, such as Bergengruen's narrative. Boccaccio mostly aimed at erotic entertainment in the first place, but he still pursued profoundly ethical and moral goals with his literary accounts, and this very point can also be identified in Bergengruen's approach.

This study intends to examine particularly Bergengruen's novella in light of the "Falkenmotiv," as Paul Heyse had called it already in 1871 (XIX-XX) and to identify the deep values formulated here which obviously appealed to a wider audience at his time. First having appeared in 1928 (not 1937, as many lexica authors in print and online claim), the 
author drew from the ideals underlying Boccaccio's narrative and utilized the central motif of the falcon to develop a literary platform for the exploration of human nobility, the desire for freedom, and the contempt of material goods in favor of human ideals (Bergengruen, Die drei Falken). This historicizing novella was re-published in 1937, 1940, 1945, 1947, 1951, 1956, 1957, 1958, 1959, 1963, 1964, 1965, 1966, 1969, 1972, 1978, 1982, 1983, 1985, 1989, 2000, 2001, translated into English in 1950 and 1966, into French in 1970, into Italian in 1962 and 1992, and into Polish in 1964. The interest in this famous story by Bergengruen seems, however, to have faded since then with no further re-publications or translations after 2001, and it would be a valuable investigation to understand the reasons for this major shift in public interests.

Yet, this study will focus on the medieval or Renaissance material in Bergengruen's narrative and intends to examine how the motif of the falcon served the author to express his ideals and why they resonated so profoundly with his audience well until the end of the twentieth century. In order to tackle our task, it will be necessary also to outline briefly Bergengruen's biography and highlight his major works, especially because he is mostly unknown in the Anglophone world and currently mostly ignored by the contemporary German-language readership, here ignoring some of his works re-issued by very small niche publishers, such as his religious poems in Dies irae (Bergengruen, 2005). But let us first get a better idea of what is meant with the 'Falkenmotiv.' Then I want to scan the history of this motif already in Middle High German literature from the twelfth and thirteenth centuries, and subsequently analyze in detail what Bergengruen made out of it.

\section{The Falkenmotiv in Boccaccio's Decameron}

In Boccaccio's Decameron (ca. 1350), we come across a story by the 'queen' of the company, Pampinea, who relates the account of Federigo degli Alberighi who has become extremely impoverished due to his failed attempts to win the love of his lady, Monna Giovanna (story 9 on Day V). This forces him to withdraw from Florence and to retire to a little country house, where he has only one valuable falcon as his last precious thing in his possession. Then, Monna's husband dies, and she and her little son move away from the city to their estate outside, which happens to be near to Federigo's. Her son soon strikes a friendship with Federigo, and is especially intrigued by the falcon, but there is no way for him to acquire this bird. Then, however, he falls severely ill, and upon his mother's inquiries, he finally admits that gaining that falcon would certainly help him to recover. His mother is rather shocked about this request, and very uncertain what to do because she is fully aware that this bird of prey is one of the finest of its species and, more importantly, her lover's single remaining source of happiness. She asks herself quite poignantly: "How can I possibly go to him, or even send anyone, to ask him for this falcon, which to judge from all I have heard is the finest that ever flew, as well as being the only thing that keeps him alive? And how can I be so heartless as to deprive so noble a man of his one remaining pleasure?" (427).

Nevertheless, driven by her maternal love for her son, Monna Giovanna then goes to visit Federigo, who is overjoyed, not knowing what her real purpose might be. Desperately he tries to prepare a welcome dinner for her, but there is no food in the house except for the falcon. 
Without thinking much about it, he kills the bird and prepares it as a meal for his lady. Only once the dinner has been finished, does she reveal what her request truly was, which is, of course, by then impossible to fulfill. Nevertheless, when she realizes what sacrifice he had made for her, her heart begins to melt, and after her son has tragically died, she decides to marry Federigo, although her brothers at first balk at the fact that the young noble man is completely impoverished. She explains her decision as follows in a well-formulated chiasm: " I am well aware of that. But I would sooner have a gentleman without riches, than riches without a gentleman"' (431-32). Already before this final outcome, she had reflected with amazement on Federigo's noble spirit, which refused to let any material constraints hamper his pursuit of love and noble behavior: "then she became lost in admiration for his magnanimity of spirit, which no amount of poverty had managed to diminish, nor ever would" (431) (Del Puppo and Musumeci).

\section{The Falcon in Courtly Love Poetry (Minnesang), Heroic Poetry (Nibelungenlied), and Courtly Romances (Wolfram von Eschenbach's Parzival and Gottfried von Straßburg's Tristan).}

Boccaccio was not at all the first and or the last to draw from the falcon as a crucial symbol for the profiling of the protagonist's character or for the power of love. In the anonymous Middle High German Nibelungenlied (ca. 1200), young Kriemhild has an ominous, much-discussed dream right in the first chapter in which she perceives a falcon, which she had raised and tamed, being torn apart by two eagles (stanza 11; Nibelungenlied 8). Even though her mother Uote interprets the falcon as a symbol of her future husband (Siegfried) and acknowledges that Kriemhild might lose him if God does not protect him (stanza 12), she subsequently dismisses the second part, the killing of the falcon, and encourages her daughter to embrace the idea of love and marriage because a woman would gain happiness only through a loving husband (stanza 14). However, the narrator quickly deprives us of all illusions and alerts us to the facts that Siegfried will be killed by his in-laws and that Kriemhild will later take horrendous revenge leading to the death of many men (stanza 17). Later, shortly before Siegfried's murder, she has another dream which also signals her husband's violent death, and although she relates it to her husband who is about to join the hunting party with his brothers-in-law in order to warn him about this prophecy, he dismisses the analysis and thus becomes the victim of Hagen's actions, as predicted by the dream (stanza 918; cf. now Samaké 136-49).

In contemporary courtly love poetry, Minnesang, especially in the stanzas by Kürenberger (II, stanzas 6-7), we also hear of the falcon, and there commonly as a symbol of inner nobility, civilization, and the taming of wild nature within male wooers of courtly ladies. The falcon might represent the lover who has left his lady, or it could symbolize the lady herself, all depending on the circumstances (Des Minnesangs Frühling). It is quite common in courtly romances to hear of references to the falcon, such as in Wolfram von Eschenbach's famous Parzival (ca. 1205), where the young protagonist comes across a field suddenly covered by snow, and this in the month of May. Shortly before that, Parzival had left his wife Condwiramurs to visit his mother (long dead by that time, but unknown to him), had arrived at the Grail but had failed to ask the crucial question, had subsequently redeemed his previous 
guilt with Jeschute, defeating her aggressive husband Orilus, and was then looking for King Arthur's court. One of the king's falconers had lost his bird, which is now following Parzival, and early in the morning tries to kill a goose. The falcon, however, fails in doing so, yet wounds one of the geese, which leaves three drops of blood in the white snow. Parzival, witnessing this color code, feels reminded of his wife, whom he deeply misses, and falls into a trance, although he is not far away from the royal camp: "Condwiramurs, truly, these colours resemble you! God desires to enrich me with blessings, since I have found your likeness here" (Wolfram von Eschenbach, Book VI, p. 119). There are no further comments on the falcon, but its instrumental function to remind Parzival of his deep love for this noble lady is quite obvious.

Quite parallel to this scene, in Tristan und Isolde (ca. 1210) by Wolfram's contemporary, Gottfried von Strassburg, the young protagonist demonstrates, mirroring his noble education and character, a strong fascination with birds of prey, which are being offered for sale by Norwegian merchants. Tristan, along with his foster-brothers, is allowed to go to their ship and to view those falcons, some of which are bought for them all. Unfortunately for Tristan, he then espies a precious chess-board and begins to play a game with one of the merchants, which makes it possible for the Norwegians to kidnap him (70-74). This then sets off a whole chain of events, which do not concern us here further. Nevertheless, the symbolic function of the falcons cannot be overlooked here at all.

We could also widen our perspective and identify numerous other examples of falcons incorporated into pan-European literature (Reiser; Ermes-Körber). Considering the supreme importance of falcons in medieval and early modern aristocratic culture, representing self-discipline, training, education, inner nobility, and character strength, it does not come as a surprise that Boccaccio also drew on this bird of prey to explore the power of love in his story (Anschütz). Hunting with falcons or other birds of prey was, after all, regarded, as the most prestigious form of sport, as illustrated by Emperor II's famous manual on how to raise, tame, and train falcons, his De arte venandi cum avibus (ca. 1241-1248) (cf. Walz).

William Shakespeare also drew on the symbolic imagery of the falcon in his Othello (1603) to explain the curious relationship between husband and wife, especially when she (Desdemona) is not willing to obey his commands and thus would have to be set free. Similarly, in Taming the Shrew (ca. 1590-1592), we hear of the falcon as representing Petruchio's wife Kate who is supposed to be disciplined, and yet refuses. In William Butler Yeats's "The Second Coming" (1919), the world is out of control and threatens to explode into chaos, which the poet expressed with the famous second line: "The falcon cannot hear the falconer" (https://poets.org/poem/second-coming; see also Bagby Jr. and Carroll).

Online articles on falcons and falconry also include numerous references to literary works focused on those birds of prey, transforming them to important symbols of love, nobility, and freedom, or situating the plot in the world of falconry, which in turn represents chivalry, knighthood, and honor. Surprisingly, however, Werner Bergengruen's famous novella does not figure there at all, and we can also be pretty certain that his work has remained mostly unknown beyond the German-speaking lands at least for several decades now, especially 
because he does not even figure in recent literary histories composed in English (Wellbery and Ryan, ed.).

Strangely, scholars of literary motifs have not yet endeavored much at all to trace the "Falkenmotiv" further, combining medieval with modern literary examples (no reference in Frenzel). He counts, however, at least for twentieth-century German scholarship, among the major writers within world literature (Wilpert, ed., 148). Yet, the very recent Companion to World Literature does not even include his name (Seigneurie, ed.). Nevertheless, as we have observed already above, Bergengruen enjoyed extensive popularity at least well into the 1980s, and some of his other works were even translated, to extend the list above, into Arabic (1971), Czech (1966), Japanese (1953, 1956, 1957, 1962, 1971, 1973), Lithuanian (1997, 1999, 2000), Estonian (1999, 2000), Korean (2000), and Chinese (1985). Hence, "Die drei Falken" might represent a literary gem which the current generation of scholars and readers seems to have lost out of sight (Kampmann), although a Bergengruen Society strives to keep his memory alive (http://werner-bergengruen-gesellschaft.de/).

In order to gain a good grip on this astonishing phenomenon, of a literary text that used to gain the highest accolades but has since then mostly disappeared from the academic horizon and from public view, we need first to examine Bergengruen's biography and his literary output, and then develop a critical analysis (Weiss). He was born on September 16, 1892, in Riga, today the capital of Latvia, and he studied at the universities of Marburg, Munich, and Berlin. He served in the military during the First World War, then turned to translating Russian literature, before he decided to become a full-time writer in 1927. In 1936, he converted to Catholicism and increasingly took a critical stance against the National Socialists. His novel Der Großtyrann und das Gericht (The Grand Tyrant and the Legal Court, 1935) quickly proved to be his masterpiece, but it also irritated the Nazis considerably, with whom he experienced conflicts both because his wife had some Jewish ancestors and because his novel could be interpreted as a criticism of the ruthless leader. Of course, Bergengruen could not have foreseen the rise of Hitler to power in 1933, when he was in the midst of writing his novel (he had begun with it in 1926), but it certainly contained major criticism of an absolutist (Renaissance) tyrant who abuses his position to torture some of his servants to solve a murder which he himself had committed.

Both Bergengruen's religious devotion and ethical stance made it difficult for the Nazis to tolerate him, so in 1937 he was expelled from the he Reichsschrifttumskammer (Reich Chamber of Culture), as he was identified as being unfit to contribute to German culture. Nevertheless, although most of his works were banned, he managed to publish despite it all, either in very small editions, or via handwritten copies. Oddly, Der Großtyrann continued to enjoy great popularity and was even printed as a field edition for soldiers at the war front. Probably because of his popularity among the common readers, the Nazis never moved against him in person. Yet, he was clearly aware of their atrocities and condemned them in his writings by way of subtle, refined prose.

This subtlety and careful approach to those severe political problems in Germany brought him on a collision course later with many authors who had been imprisoned or had to find 
refuge in exile, while Bergengruen enjoyed his relatively care-free life there. But in 1945, he famously stated: "Niemand darf sagen, er habe von den Greueln nichts gewußt. . . . Was in den Konzentrationslagern geschah, das wußte jeder, wenn er nicht Gehör und Gesicht gewaltsam verschloß" (No one may say that he did not know anything about the horrors. . . Everyone knew what happened in the concentration camps, unless one closed up both ears and the brain) (quoted from Klee, 44; see also Kroll, Hackelsberger, and Taschka, 2005). Certainly, Bergengruen leaned rather conservative, which is also reflected in his strong emphasis on historical themes in his many short stories and novels, but his criticism of the mighty, especially of tyrants, his comments on destiny, honor, and love, certainly found a wide readership after the war as well.

After the war, Bergengruen moved to Switzerland, then to Rome, and finally to Baden-Baden, Germany, where he died in 1964. He was a prolific author and left behind an extensive literary œuvre, but today he no longer enjoys the previous popularity and almost seems to have been forgotten, maybe because of his traditionalist and religious views. Older scholarship characterized his work as deeply shaped by the awareness of destiny determining human existence, of nature influencing human life, and the strong belief in a divine order ruling above all (Kroll, 1997). But there is much more satire, criticism of political subjugation, and a subtle humor to be found in his narratives, especially in his collection of short stories, Der Tod von Reval (1937; Death of Reval [today: Tallinn, Estonia]), among others. Life and death are closely intertwined here, and so are love and death in other works, such as Die Feuerprobe (1933; The Fire Ordeal).

Human frailty in face of political repression, or in situations of war and destruction, becomes revealed in numerous texts by Bergengruen, such as Am Himmel wie auf Erden (1940; In Heaven as on Earth), or Die Schatzgräbergeschichte (1943; The Story of the Treasure Hunter). For Bergengruen, the deepest secrets of life are hidden in the heart, as he often formulated also in his poems, such as Dies irae (1946; The Day of Wrath); Die heile Welt (1950; The Wholesome World), and Figur und Schatten (1958; Figure and Shadow) (Ried, 360-62; Scholz). The task for people would consist, as we read in Das Tempelchen (1950; The Little Temple), to search for a key that would allow them to decode the secrets of life (6). Or, as the grandmother as narrator emphasizes, "auf das Herz des Menschen kommt es an, und nicht auf seine Sprache oder auf die Gedanken in seinem Kopf" (9; what matters is the heart of a human being, not his language or the thoughts in his head).

Maybe the historical framework has made it difficult for the current generation to appreciate Bergengruen's work fully, but more importantly, so it seems, his efforts to probe philosophical aspects in the human existence as viewed through the historical lens, combined with at times an almost mystical perspective, might make his work less appealing today. Many times, the author explored historical themes, such as in his Herzog Karl der Kühne oder Gemüt und Schicksal (1935, republished many times thereafter), which allowed him to evade the attacks by the Nazi and to hide in the 'inner exile' (Hermand).

The novella Die drei Falken proves to be intriguing both as a jewel of short prose writing in German, and as a literary document illustrating the extent to which medieval and early 
modern topics continue to have an impact on contemporary literature. I would also like to suggest that it could serve as a gateway for the rediscovery of Bergengruen as a major literary voice from the middle of the twentieth century. The author situates the events in a southern Italian town within the kingdom of Naples. The historical time frame is somewhat vague, but the reference to the dying art of hunting with falcons indicates that Bergengruen intended to date it to the fourteenth or fifteenth centuries. The 'protagonist,' though appearing only in the background, could be identified as an old master of falconry who passes away already at the beginning of the story and leaves behind basically nothing but three most valuable falcons. The critical question explored in this narrative is how these falcons are then auctioned off and what they mean for those who are either identified as heirs or who desire nothing more but to acquire one of those falcons.

Although this old man lived a rather impoverished life, just as Federigo did in Boccaccio's story after he had wasted all of his money in wooing Monna Giovanna, his art and his falcons were highly sought after. At the same time, there is a fraternity in that town dedicated to this hunting sport, calling itself after their patron saint, St. George. Their goal consists of promoting and advocating the traditional values of medieval chivalry and ideals, so they have imposed strict admission guidelines, operating like a secret society (5-6). This old falconer then passes away, and the fraternity takes it upon itself to pay its deepest respect for their master, paying for a splendid funeral (6). In fact, as we later hear, this old man had been "der Ruhm unserer Stadt" (15; the fame of our city), and so it does not come as a surprise that everyone of rank and money is most interested in acquiring one of the three surviving falcons, their master's inheritance.

But the focus quickly shifts to the haggling over the falcons and over who would be entitled to receive the payments for the falcons as stipulated in the last will. This old man constantly remains in the center of attention throughout the entire story like a cameo figure, both because of his extraordinary skills in training and taming falcons, and because he was the owner of those three valuable birds. While not really present any longer, his ideals and values constitute the ethical background and foundation upon which the entire novella hinges.

Three facts about this man are mentioned almost just in passing, but they matter critically for the development of the entire novella. The narrator informs us, first, that this man had originated from a northern country, the name of which is not given. Second, he had lost his wife early and then also his only son. The latter's widow had subsequently married a rich silk merchant, who emerges as a rather aggressive and greedy claimant in the heated debates over how the money would have to be distributed among the heirs as designated by the deceased man in his last will. And third, he had lived in a simple apartment built right on to the city wall and overlooking the entire landscape below it. As the narrator implies, the second floor appears almost like a bird's nest in the mountains from where he could "weit hinaus[ ]spähen und die Masse des gefiederten Volkes unter sich [ ] sehen" (7; gaze far and wide and see the mass of feathered people [birds] below him). This falconer was like one of his own noble birds of prey, free and independent, the ideal embodiment of what the fraternity of falconers wants to achieve: "die Bewahrung einer grossherzigen Sinnesart und ritterlicher Sitten" (6; the preservation of a generous attitude and chivalric habits). 
Accordingly, the payment for one falcon was to be used to settle all of the bills by merchants and craftsmen, and the remaining amount was then to be spent on a public dinner for the poor in the city (16-17). The payment for the second falcon is to be turned over to the monastery of the Holy Ghost so that the monks would read masses for the deceased. The money to be paid for the third falcon is to be divided among the heirs (17). But there is no blood relative of the falconer, except, which shocks everyone among the assembled witnesses and interested parties, a younger man identified as Cecco, a slightly handicapped individual whose nickname has thus become 'the limper,' a person without any steady job or any solid education.

As we are told, he works at times as a public entertainer, especially as a marionette player, as messenger, temporary bar helper, and as a violin player at weddings where he creates many new tunes. Due to the fact that he was born illegitimately, he was never allowed to learn a proper craft and is thus condemned to live the life of a marginalized person (14). But, as the narrator emphasizes, he is characterized by a "freiherzige[ ], unbekümmerte[ ] und für keine gescheite Zukunftssorge taugliche[ ] Wesenszug" (14; a nature determined by a free spirit, lack of care, and an inner attitude making it impossible for him to prepare decently for his future). In a way, Cecco represents the artist per se, the independent mind, and hence he appears as the very contrast to the wealthy and yet very insensitive silk merchant who feels only contempt for him.

As much as the silk merchant - never mentioned by name - tries to claim full inheritance rights, the lawyer Albinelli, in charge of the handling of the auctioning of the falcons, denies that and operates very delicately in this matter. This man actually emerges as the second true protagonist, next to the deceased falconer, because he had embraced the falconer as his admired teacher and friend (15). In fact, Albinelli proves to be entirely obsessed with falconry and plans on purchasing one of the falcons at any cost. Those birds are identified as belonging to a noble type of falcons, which kill their prey in the air, whereas the not so noble kind picks up its prey from the ground (10-11). As the old woman, who had taken care of the falconer's household, explained to the silk merchant and his wife, the noble falcons "fliegen rasch, wohin sie wollen" (11; fly quickly wherever they want). However, they lack the ability to stay in the air for a longer time, waiting for some prey to appear on the ground, which characterizes the other type.

The wife of the silk merchant tries to differentiate herself socially from Cecco, comparing herself and her husband with the 'noble falcons,' whereas the 'good-for-nothing' would be one of the 'unnoble falcons' (19). In parallel, Albinelli expresses some soft contempt for the written document as formulated by the deceased man because it reflects an untrained legal mind. But again, the contrast between noble and unnoble falcons comes to the fore because the old man had not been able to handle that business in the proper way, just as the noble falcons "sich auf dem Erdboden ungewandt und plump bewegen" (20-21; move around on the ground in an awkward and lame manner). Free movement in the air, liberated from the earth's gravity, both the falconer, in a way, and his falcons had moved and acted, and this will also find its confirmation at the end. 
In the meantime, however, Albinelli learns that one of the three falcons has flown away and might not be retrievable, which causes considerable legal and financial problems for everyone involved, especially because the silk merchant struggles hard to get the most money out this inheritance, even at the cost of the poor in the city, claiming that the monastery or the merchants should bear the loss, a procedural strategy, however, in which he is not successful.

The subsequent legal and argumentative details do not concern us here, and instead, we can turn to the actual auction, in which Albinelli at first holds back out of politeness. But he tries his best to bid the most for the second falcon, when by chance the third bird, which had escaped, is brought back having been trapped by accident.

All attention is then focused on this falcon, a bird which had sought its freedom when an occasion had arisen, but then was caught again by accident. Everyone believes that this is the noblest falcon, so the bidding promises to become particularly intense. Albinelli is also most eager to acquire just this bird, as if all of his good fortune and life depended on it (48), but he first calls for a break which allows everyone to inspect the falcon and to admire its appearance and fierce and noble character (48). This leads over to the critical moment in this story, which is so characteristic of 'classical' novellas, with Cecco approaching the table where this falcon, now tied down, is resting (50). He calmly puts on one of the gloves with which it is possible to place a falcon on one's fist without its talons hurting the person. Immediately, the previously nervous and aggressive bird calms down, submitting, so to speak under Cecco's will. At that moment, people observe Cecco's surprising similarity with his biological father (51), which signals already here the connection between the limping man and the bird, both desirous of freedom: "Inbild aller königlichen Herzensfreiheit" (51; representation of all royal freedom of the heart).

For Cecco, the real problem consists of the commercialization of these birds, the haggling, negotiations, buying and selling, that is, the reification of these noble living creatures. With his shoulders only he expresses his "Widerwillen[ ]" (51; repugnance) against all those attempts to sell the bird to the highest bidder, which the falcon obviously senses in a subtle way. In fact, the bird begins to gaze at Cecco, who suddenly feels even an "Ekel" (51; disgust) about the monetary thinking of all those people around him, especially of the silk merchant and his wife. Moreover, he begins to fear that this monetary attitude by all the others might engulf him as well for the rest of his life, which makes him feel like a contemptible figure (52). Bird and man stare into each other's eyes, when Cecco quietly releases the fetters with which the falcon is held tightly, then lifts the right arm with which he is holding the bird, and suddenly lets it fly freely, away from the crowd, soon soaring high above their heads, and quickly disappearing in the air above them all.

The crowd watches this scene with amazement, and keeps completely quiet, until the children of the silk merchant break out in happy shouts, jubilating about the falcon which has regained its freedom (52). As children, their minds are not yet occupied with commercial interests, which is a kind of mirror phenomenon with Cecco, who stands there and smiles, though he then pretends to be chagrined about his alleged clumsiness in handling the bird. The narrator describes almost breathlessly the beauty of the bird which swings its wings higher and higher 
and soon disappears from view, now enjoying what it naturally wanted, its freedom.

The real victim of this incidence proves to be Albinelli who virtually collapses out of deep frustration because all of his desires had been focused on this falcon. The silk merchant also demonstrates extreme fury, but only because he has lost the badly hoped-for money for the falcon (53). He and his wife would have punched and beaten up Cecco if they could have gotten hold of him, while Albinelli almost breaks down, covering his face in deep despondency. The prior of the monastery which had been promised the profit from the second falcon tries to console the lawyer and reminds him of the most valuable copy of the book of falconry by Frederick II. It would retain its true value, long beyond the death of everyone alive at that time, including the falcons (55). These words might have reached Albinelli's heart, which had been in danger of being devoured by his greed and hatred against Cecco. When the latter is brought back to him, however, the lawyer suddenly displays a very different attitude. While he still blames the limper for having caused him profound pain, he finally admits that he himself had misunderstood the entire purpose of taming and training falcons. The deceased man had never thought of financial profit when he practiced his art and had demonstrated a lack of interest in material goods, an inner freedom which had basically led to his poverty (5). Instead, as Albinelli then formulates quintessentially, the true purpose of hunting with falcons rests in the realization that "im menschlichen Herzen etwas beschlossen liegt, welches der Sinnesart des Falken entspricht" (p. 55; something is hidden in the human heart which is equivalent to the falcon's nature).

The novella then comes abruptly to its conclusion, but not without a final surprising action. Albinelli takes off the silver chain necklace, which identifies him as a member of the falconry fraternity, and places this valuable symbolic object on Cecco, signaling that this illegitimate son of the famous falconer had understood more about these birds of prey when he had granted it its freedom than they all together in their base desire to make the most money from the falcons or to take possession of one of them. Both himself and the silk merchant, the other bidders and the audience had mainly thought of profit or had been lost to their excessive passion, meaning that they had become victims of their greed. The lawyer, above all, realizes his profound misconception of what falcons are really all about; they are not to be used as possessions, but deserve to be respected as noble birds. Their training is not aimed at crushing their will and enslaving them. Instead, a well-trained falcon becomes the owner's friend and voluntarily returns to his fist to be fed, so falcon and falconer turn into a team of hunters of the highest caliber.

The freed falcon and Cecco thus emerge as similar in their nature and character, and this also applies to the deceased falconer. The young man had recognized the bird's noble nature which should not be submitted to human control, so granting the falcon the desired freedom was a sign of greatest respect for this noble bird. Boccaccio had used the falcon for the very same purpose, though the circumstances are quite different in his account. Those who work with falcons thus prove to be noble in their inner self, unless they try to hold on to them obsessively, such as Albinelli. For that reason, this lawyer and falcon lover passes his chain necklace on to Cecco because he had demonstrated a deeper understanding of what noble falcons really are than himself who had almost betrayed his own ideals when he had tried so 
hard to bid for the third bird. The narrator's final words underscore how much the lawyer's action struck a deep chord in all present. No one says a word, there is no applause, but all of their hearts quivered in awe, in shame over their own behavior, or because they felt spiritually uplifted (55).

From here we could turn our attention also to a modern movie, "The Eagle Huntress" (2016), where the thirteen-year-old Kazakh girl from Mongolia, Aisholpan succeeds in following her father's and many of her ancestors' footsteps and becomes a master in the art of training eagles. While the focus in the movie rests on the girl's effort to break the gender ceiling and to join a men's sport, in essence the film also pinpoints the reason for Aisholpan's triumph, which rests in her 'partnership' and 'friendship' with her own eagle, a truly noble bird, like the young woman.

To conclude then, Bergengruen's novella proves to be such a literary gem because it provides a unique literary expression for this ideal of inner nobility, the nobility of the heart, as to be found in the falcon, in the deceased falconer, and in his illegitimate son Cecco. The latter allows the third falcon to return to freedom because he is disgusted with the commodification of these noble birds and rather sets the third one free than to be caught up himself in this monetary thinking. His artistic nature sets him radically apart from the silk merchant and his wife, but also from the obsessive lawyer Albinelli, who understands only at the very end how much he himself had betrayed the very values of their fraternity, which was predicated on the realization of the noble character of those falcons which really deserved to be free.

\section{References}

Anschütz, R. (1892). Boccaccios Novelle vom Falken und ihre Verbreitung in der Litteratur. Erlanger Beiträge zur englischen Philologie und vergleichenden Litteraturgeschichte, 13(3).

Bagby, Jr., Albert, I., \& William, M. C. (1970). The Falcon as a Symbol of Destiny: De Rojas and Shakespeare. Romanische Forschungen, 83(2-3), 306-10.

Bergengruen, W. (1945). Dies irae, epilogue and commentary by Rudolf Grulich, Juwelen religiöser Dichtung, 3. Hess 2008.

Bergengruen, W. (1947). Die drei Falken. Zürich: Arche.

Bergengruen, W. (1950). Das Tempelchen. Munich: Nymphenburger Verlagshandlung.

Boccaccio, G. (1992). The Decameron. Trans. with an intro. and notes by G. H. McWilliam. Sec. ed. London: Penguin.

Classen, A. (1996). Seinskonstitution im Leseakt: Adolf Muschgs Der Rote Ritter als Antwort auf eine mittelalterliche These. Etudes Germaniques, 51(2), 307-327.

Classen, A. Hermann Hesses Glasperlenspiel (1943) und James Hiltons Lost Horizon (1933). Die Intertextualität zweier utopischer Entwürfe. Studia Neophilologica, 72, 190-202. https://doi.org/10.1080/003932700458045

Dallapiazza, M. (Ed.). (2003). Tristano e Isotta: La fortuna di un mito europeo, Quaderni di 
Hesperides. Serie Manuali, 1. Triest: Edizioni Parnaso.

Das Nibelungenlied: Mittelhochdeutsch / Neuhochdeutsch. Nach der Handschrift B herausgegeben von Ursula Schulze. Ins Neuhochdeutsche übersetzt und kommentiert von Siegfried Gross. Philipp Reclam jun. 2010.

Del Pupo, D., \& Salvatore, M. (2010). "Predators of the Heart: Nobility, Eroticism, and Changing Food Practices in the Tale of Federigo degli Alberighi (Decameron V.9)." Table Talk: Perspectives on Food in Medieval Italian Literature, ed. Christiana Purdy Moudarres. Newcastle-upon-Tyne: Cambridge Scholars Publishing, pp. 73-84.

Des Minnesangs Frühling, ed. Hugo Moster and Helmut Tervooren. Vol. I: Text. 38th newly rev. ed. Stuttgart: S. Hirzel 1988.

Ermes-Körber, Antonia Gertruda. "Zwei Künste, beflügelt von einem Ideal: eine Untersuchung des Falkenmotivs in der Lyrik, Epik und Minneallegorie des 12. - 14. Jahrhunderts.” Ph.D. Diss., Amsterdam 1995.

Frenzel, Elisabeth. Motive der Weltliteratur: Ein Lexikon dichtungsgeschichtlicher Längsschnitte. 4th rev. and expanded ed., Kröners Taschenausgabe, 301. Stuttgart: Alfred Kröner Verlag, 1992.

Gottfried von Strassburg. Tristan. With the surviving fragments of the Tristran of Thomas. With an intro. by A. T. Hatto. London: Penguin, 1960/1967.

Grosse, Siegfried and Ursula Rautenberg. Die Rezeption mittelalterlicher deutscher Dichtung: Eine Bibliographie ihrer Übersetzungen und Bearbeitungen seit der Mitte des 18. Jahrhunderts. Tübingen: Max Niemeyer Verlag 1989.

Hermand, Jost. Kultur in finsteren Zeiten: Nazifaschismus, Innere Emigration, Exil. Cologne: Böhlau 2010. https://doi.org/10.7788/boehlau.9783412213107

Heyse Paul and Hermann Kurz, ed. Deutscher Novellenschatz. Vol. 1. Rudolph Oldenbourg, [1871].

Kampmann, Theoderich. Das Verhüllte Dreigestirn. Werner Bergengruen, Gertrud von le Fort, Reinhold Schneider, Schriften zur Pädagogik und Katechetik, 24, Ferdinand Schöningh, 1973.

Klee, Ernst. Das Kulturlexikon zum Dritten Reich. Wer war was vor und nach 1945. S. Fischer, 2007.

Kroll, Frank Lothar. Dichtung als Kulturvermittlung: der Schriftsteller Werner Bergengruen: Beiträge für Unterricht und Weiterbildung, Die Deutschen und ihre Nachbarn im Osten, Geschichte und Gegenwart, 7. Haus der Heimat des Landes Baden-Württemberg, 1997.

Kroll, Frank-Lothar, N. Luise Hackelsberger, and Sylvia Taschka. Werner Bergengruen Schriftstellerexistenz in der Diktatur. Aufzeichnungen und Reflexionen zu Politik, Geschichte und Kultur 1940 bis 1963, Biographische Quellen zur Zeitgeschichte, 22, Oldenbourg, 2005. https://doi.org/10.1524/9783486707823.27 
Reiser, Irmgard. "Falkenmotive in der deutschen Lyrik und verwandten Gattungen vom 12. bis zum 16. Jahrhundert.” Ph.D. diss. Würzburg 1963.

Ried, Georg. Wesen und Werden der deutschen Dichtung. Verlag M. Lurz, 1966.

Risden, Edward L. Tolkien's Intellectual Landscape. McFarland \& Company, 2015.

Samaké, Abdoulaye. Liebesträume in der deutsch-, französisch- und italienischsprachigen Erzählliteratur des 12. bis 15. Jahrhunderts, Traum - Wissen - Erzählen, 6, Brill and Wilhelm Fink 2020. https://doi.org/10.30965/9783846764770

Scholz, Ingeborg. Deutsche Lyrik im Spannungsbogen zwischen Kunst und Religion, Werner Bergengruen und Rudolf Alexander Schröder, Disputationes linguarum et cultuum orbis: Sectio V, Volkskunde und Germanistik, 6. Verlag für Kultur und Wissenschaft, 2002.

Seigneurie, Ken, ed. A Companion to World Literature, 6 vols. Wiley Blackwell 2020. https://doi.org/10.1002/9781118635193

The Eagle Huntress. https://www.sonyclassics.com/theeaglehuntress/

Tristania: A Journal Devoted to Tristan Studies, 1975-2009, 25 vols.

Wagner, Fritz. Zum Mittelalterbild der Brüder Grimm. Verlag Dr. Kovač, 2005.

Walz, Dorothea. Das Falkenbuch Friedrichs I. Akademische Druck- und Verlagsanstalt, 1994.

Weiss, Gerhart H. "Werner Bergengruen." Dictionary of Literary Biography, vol. 56: German Fiction Writers, 1914-1945, ed. James Hardin. Gale, 1987, https://go-gale-com.ezproxy1.library.arizona.edu/ps/retrieve.do?inPS=true\&userGroupName =uarizona_ main\&prodId=DLBC\&docId=GALE|GBLYOY708023134

Wellbery, David E. and Judith Ryan, ed. A New History of German Literature. The Belknap Press of Harvard UP, 2004.

Wilpert, Gero von, ed. Lexikon der Weltliteratur: Biographisch-bibliographisches Handwörterbuch nach Autoren und anonymen Werken. Alfred Kröner Verlag, 1963.

Wolfram von Eschenbach. Parzival and Titurel, trans. Cyril Edwards. Oxford World's Classics. Oxford UP, 2004, 2006.

Yeats, William Butler. “The Second Coming” (1919). https://poets.org/poem/second-coming.

Zipes, Jack, ed. The Oxford Companion to Fairy Tales. Oxford UP, 2000.

\section{Copyrights}

Copyright for this article is retained by the author(s), with first publication rights granted to the journal.

This is an open-access article distributed under the terms and conditions of the Creative Commons Attribution license (http://creativecommons.org/licenses/by/4.0/) 